\title{
Clinical Pharmacy Practices in Oncology Patients Treated with Tyrosine Kinase Inhibitors
}

\author{
Kamer TECEN-YUCEL ${ }^{1}$, Aygin BAYRAKTAR-EKINCIOGLU ${ }^{1}$, \\ Saadettin KILICKAP², Mustafa ERMAN² \\ ${ }^{1}$ Hacettepe University, Faculty of Pharmacy, Department of Clinical Pharmacy \\ ${ }^{2}$ Hacettepe University, Institute of Cancer, Department of Medical Oncology, Ankara, TURKEY
}

\begin{abstract}
Tyrosine kinase inhibitors (TKIs) have a good efficacy profile in treatment of cancers but also have a potential risk for drug interactions and adverse effects. The aim of this study was to identify and evaluate drug-drug interactions and adverse effects related to TKls in patients by the involvement of a clinical pharmacist within an outpatient setting. This study was conducted at an outpatient clinic of the University Oncology Hospital between October 2015 and April 2016. The patients on TKIs treatment were included and monitored during 3 months by a clinical pharmacist. The severity and a clinical significance of drug interactions were assessed by using different information resources. An occurrence of adverse effects in patients was evaluated in the first and the second visits. Fifty-five patients were included in the study. A total of 92 drug interactions were identified, of those 54 (58.69\%) were assessed as a clinically significant. Among clinically significant drug interactions, a pharmacist recommended treatment modifications for 18 drug interactions, all were accepted by doctors and necessary modifications were implemented. Adverse effects $(n=32)$ were identified in 55 patients during the 3 months where a pharmacist made 32 recommendations, of which 29 (91\%) were accepted by doctors. Statistically significant decrease was found in the number of occurred gastrointestinal disorders $(p=0.001)$ and fatigue $(p=0.021)$ between the first and the second visits. Close monitoring of patients by clinical pharmacists whom are integrated into the outpatient settings may further contribute to the health outcomes in collaboration with a multidisciplinary team in oncology.
\end{abstract}

Keywords: Tyrosine kinase inhibitors, Drug interactions, Adverse effects, Clinical pharmacist

ÖZET

Tirozin Kinaz İnhibitörleri ile Tedavi Edilen Onkoloji Hastalarında Klinik Eczacılık Uygulamaları

Tirozin kinaz inhibitörleri (TKI), birçok kanser tedavisinde iyi bir etkinlik profiline sahip olmakla birlikte, ilaç etkileşimleri ve advers etkiler açısından da bir risk potansiyeline sahiptir. Bu çalışmanın amacı; tirozin kinaz inhibitörleri kullanan hastalarda klinik eczacının tedavi izlemine katıımı ile ilaç-ilaç etkileşimlerinin ve yan etkilerin saptanması ve değerlendirilmesidir. Bu çalışma Ekim 2015-Nisan 2016 tarihleri arasında bir Üniversite Onkoloji Hastanesinin polikliniğinde gerçekleştirilmiştir. TKi kullanan hastalar çalışmaya dahil edilmiş ve tedavileri 3 ay boyunca bir klinik eczacı tarafından izlenmiştir. Illaç etkileşimlerinin derecesi ve klinik önemi farklı bilgi kaynakları kullanılarak değerlendirilmiştir. Yan etkiler, birinci ve ikinci vizitlerde değerlendirilmiştir. Çalışmaya 55 hasta dahil edilmiştir. Toplam 92 ilaç etkileşimi saptanmış ve bu etkileşimlerin 54 (\%58.69)'ü Klinik olarak anlamlı bulunmuştur. Klinik anlamlı bulunan ilaç etkileşimlerinin 18'i ile ilgili olarak eczacı tarafından, doktorlara öneride bulunulmuş ve tüm öneriler kabul edilerek tedavide gerekli değişiklikler yapılmıştır. Üç ay boyunca 55 hastada 32 yan etki etki saptanmış ve buna yönelik 32 öneride bulunulmuş, 29'u (\%91) doktorlar tarafından kabul edilmiştir. Gözlenen yan etiler açısından, gastrointestinal rahatsızlıklar ( $p=0.001)$ ve yorgunluk $(p=0.021)$ gibi yan etkilerin gözlenme sayısında birinci ve ikinci vizitler arasında istatistiksel olarak anlamlı bir azalma saptanmıştır. Hastaların yakın izlemini yapan klinik eczacıların poliklinik bakım hizmetlerine entegre edilmesi, onkolojide multidisipliner ekip ile işbirliği sağlayarak, sağlık hedeflerine daha fazla katkıda bulunabilir.

Anahtar Kelimeler: Tirozin kinaz inhibitörleri, Illaç etkileşimleri, Yan etkiler, Klinik eczacı 


\section{INTRODUCTION}

Tyrosine kinase inhibitors (TKIs) have been widely used in the treatment of many cancers recently. They are generally considered safe and effective alternatives to cytotoxic chemotherapy, nevertheless, certain adverse effects may lead to dose interruptions, reductions or delays in treatments. ${ }^{1}$ They are generally given in oral, fixed-dose formulation that leads to interpatient variability in drug pharmacokinetics leading to difficulties in reaching and maintaining efficacious drug plasma levels. ${ }^{2}$ Many TKIs (e.g. sorafenib, sunitinib, gefitinib) are metabolized by cytochrome P450 (CYP 450) enzymes in liver and therefore have a potential for drug interactions, especially in cancer patients for whom polypharmacy is a common entity. ${ }^{3}$ It is known that approximately $60 \%$ of cancer patients are elderly and of those $80 \%$ have comorbid conditions which require corresponding medications that may increase the risk of drug interactions. ${ }^{4}$ Studies indicate that drug interactions with TKIs are common $^{5-7}$, therefore patients should be monitored in terms of unexpected adverse effects (particularly for cardiovascular and dermatological side effects) and clinical pharmacists are in a unique position to identify and prevent these interactions and potential adverse effects in oncology settings. ${ }^{6}$

Many studies have shown that the involvement of a clinical pharmacist in the treatment of cancer patients reduces the risks associated with drugs and improves patients' quality of life ${ }^{8-16}$, but not many studies explored the impact of drug interactions on patient's health or treatment outcomes such as hospitalization, mortality or discontinuation due to adverse effects. Moreover, few studies in literature explored the contribution of a clinical pharmacist within outpatient care of patients using tyrosine kinase inhibitors. Therefore, in this study, we aimed to detect and evaluate potential drug interactions and adverse effects related with TKIs by the involvement of a clinical pharmacist in patients using tyrosine kinase inhibitors.

\section{PATIENTS AND METHODS}

This was descriptive, cross-sectional, prospective study conducted between October 2015 and April 2016 at the medical oncology outpatient clinic of a University Oncology Hospital. The clinic is run by two consultant doctors and there were no pharmacists involved in the outpatient care prior to this study.

A sample size calculation indicated to include a minimum of 53 patients for the study.

Patients who were older than 18 years, treated and monitored within outpatient clinic during the study period, able to communicate, have been on monotherapy with one of the following TKIs that have been available at the time of the study (erlotinib, pazopanib, sunitinib, axitinib, crizotinib, sorafenib, vemurafenib, imatinib, dabrafenib and regorafenib) were considered eligible for a participation. The patients have already been on the TKI therapy and the new-starts were included. The patients were verbally informed about the study by a clinical pharmacist and asked for a consent for participation. A written consent was obtained from the participants during October and December 2015. The patients who did not fulfill the inclusion criteria, did not give a written consent or considered not eligible by his/her doctor were excluded.

Each patient was monitored by a clinical pharmacist on every visit during the three months (January-March 2016) for potential drug interactions and adverse effects. Information regarding patient's demographics, drug treatments, comorbid conditions and laboratory results were recorded.

The severity and clinical significance of drug interactions were evaluated by a clinical pharmacist using different information resources (e.g. Micromedex ${ }^{\circledR}$, Drugs.com ${ }^{\circledR}$, Medscape ${ }^{\circledR}$ and literature). Drug interactions classified by the resources as major and/or contraindicated were considered as clinically significant for the study.

TKI-related adverse effects were monitored and evaluated by using the National Cancer Institute Common Toxicology Criteria for Adverse Effects (NCI-CTCAE) version 4 where majority of adverse effects are graded on a scale between 1 (mild) to 5 (death related). The NCI-CTCAE consists of 26 criteria for adverse effects, however 11 criteria were used in this study which includes criteria related with blood and lymphatic system disorders; infections and infestations; renal and urinary disorders; gastrointestinal disorders; hepa- 
tobiliary disorders; nervous systems disorders; cardiac disorders; respiratory, thoracic and mediastinal disorders; skin and subcutaneous tissue disorders; psychiatric disorders; general disorders and administration site conditions.

The participated patients were verbally informed about actual and potential adverse effects of TKIs and precautionary approaches were explained by a clinical pharmacist where necessary. The pharmacist made recommendations to clinicians about management of drug interactions and adverse effects and the acceptance and/or rejection of recommendations by doctors was also recorded.

The data were evaluated using descriptive statistics (mean, median, percentages, and interquartile range). An analysis of normal distribution was undertaken before any statistical tests were performed. McNemar test or Wilcoxon Sign test was used to compare categorical and non-categorical data of dependent groups, respectively. A statistical significance was expressed as $\mathrm{p}<0.05$. The IBM ${ }^{\circledR}$ SPSS version 22 (IBM Corp. Released 2012, Armonk, NY, USA) was used for the statistical analysis of the data in the study.

The study was approved by the Hacettepe University Institute of Health Sciences Non-interventional Clinical Research Ethics Committee (No: GO 15/585), which assured the principles set forth in the Declaration of Helsinki 1975, revised Hong Kong 1989.

\section{RESULTS}

A total of 55 patients were included in the study; $67.3 \%$ were male and the median age was 60 (range 28-79) years. Among the participants, one patient was smoker (5-6 packet/year), one patient was a social drinker and 5 patients $(9.1 \%)$ were concurrently using herbal products beyond physician's knowledge. The demographic details of the patients are indicated in Table 1. The patients were reviewed by a clinical pharmacist on monthly basis during the study period where 55, 37 and 13 patients were followed during the 1st, 2 nd and 3rd visits respectively. The reasons for dropouts during the following visits were patient being exitus ( $\mathrm{n}=$ 3 ), discontinuation of TKI due to disease progres-

\begin{tabular}{|ll|}
\hline \multicolumn{2}{|l|}{ Table 1. Demographics of the patients in the study $(\mathrm{n}=55)$} \\
\hline & $\mathbf{n}(\%)$ \\
\hline Cancer type & \\
Metastatic non-small cell lung cancer & $20(36.4)$ \\
Metastatic renal cell carcinoma & $19(34.6)$ \\
Bone and soft tissue cancer & $5(9.0)$ \\
Others & $11(20.0)$ \\
Currently used tyrosine kinase inhibitors & \\
Pazopanib & $15(27.3)$ \\
Erlotinib & $14(25.4)$ \\
Sunitinib & $7(12.7)$ \\
Axitinib & $5(9.1)$ \\
Crizotinib & $5(9.1)$ \\
Sorafenib & $3(5.5)$ \\
Vemurafenib & $3(5.5)$ \\
Imatinib & $1(1.8)$ \\
Dabrafenib & $1(1.8)$ \\
Regorafenib & $1(1.8)$ \\
Other chronic diseases & \\
Hypertension & $19(34.5)$ \\
Diabetes mellitus & $9(16.4)$ \\
Hypothyroidism & $4(7.3)$ \\
Myocardial infarction & $3(5.5)$ \\
Prostate hyperplasia & $3(5.5)$ \\
Hyperlipidemia & $3(5.5)$ \\
Others & $10(18.2)$ \\
& \\
\hline
\end{tabular}

sion $(n=4)$ and patients not attended visits. The median duration of TKI treatment was 8.61 months (range 0.4-48) at the recruitment time of the study.

The majority of patients $(n=33)$ had comorbid diseases and therefore were on other medications. The mean number of medications per patient was $4.12 \pm$ 2.35 drugs. The most commonly used medications were antihypertensive drugs (52.7\% and $64.9 \%)$, antithrombotics (32.7\% and $37.8 \%$ ) and proton pump inhibitors / antacids (29.1\% and $21.7 \%)$ at the 1 st and the 2 nd visits respectively.

\section{Tyrosine Kinase Inhibitors and Drug Interactions:}

A total of 92 interactions were detected and 54 $(58.7 \%)$ were evaluated as clinically significant by a clinical pharmacist which required intervention such as patient monitoring, changes in drug treatment or drug administration time. Among clinically significant interactions, 18 (in 13 patients) 
Table 2. Distribution of potential drug interactions

\begin{tabular}{|llcl|}
\hline & \multicolumn{2}{c|}{ Number of drug interactions } \\
\cline { 2 - 4 } Type of Drug Interactions & TKIs - other medications & Among other medications & Total \\
\hline Identified from databases & 29 & 63 & 92 \\
Requires intervention; & 18 & 36 & 54 \\
$\quad$ only follow up & 4 & 32 & 36 \\
treatment changes & 14 & 4 & 18 \\
\hline
\end{tabular}

required changes in drug treatment or time of administration, 36 were related with patient monitoring. All recommendations were accepted by the clinicians. The number of identified drug interactions is shown in Table 2.

\section{Adverse Effects Related with Tyrosine Kinase Inhibitors:}

During the study period, a total of 32 recommendations for the management of adverse effects were suggested by a clinical pharmacist and 29 $(90.6 \%)$ were accepted by consultant doctors. The most common recommendations (31.3\%) were related to close monitoring of thyroid stimulating hormone (TSH) levels. The majority of identified adverse effects were dry skin (15.6\%) and dry eyes $(12.5 \%)$ due to erlotinib treatment and increased TSH levels due to pazopanib (12.5\%) and sunitinib $(12.5 \%)$ treatments. Table 3 shows the examples and management strategies of TKI related adverse effects identified by a clinical pharmacist.

The adverse effects were evaluated by a clinical pharmacist as 'absent' or 'present' at each patient's visit. There was a significant decrease occurred in the number of gastrointestinal disorders $(\mathrm{p}=0.001)$ and fatigue $(\mathrm{p}=0.021)$ between the 1 st and the $2 \mathrm{nd}$ visits (Table 4).

A clinical pharmacist further evaluated the severity of adverse effects according to the NCI-CTCAE version 4 on a five-point assessment scale; where 1 indicates 'mild' and 5 indicates 'death related' adverse events. The Wilcoxon t-test was performed for an analysis of severity of the assessments for 37 patients who were evaluated both at the 1st and the 2 nd visits. Although no statistically significant decrease was found in the severity of adverse effects related between the 1 st and the 2 nd visits, clinically significant improvements in patients were observed in criteria related to dry skin, diarrhea, fatigue, infection, hematuria, acute kidney injury, vomiting, salivary duct inflammation and alanine aminotransferase levels.

Fluctuations in thyroid function tests related with TKI treatment was detected by the pharmacist in 8 patients ( 3 patients were on sunitinib, 3 patients on pazopanib and 2 patients on axitinib) where

\begin{tabular}{|lll|}
\hline Table 3. Examples of TKI related adverse effects & & \\
\hline Adverse effect & $\begin{array}{l}\text { Recommendation by } \\
\text { a clinical pharmacist }\end{array}$ & Outcomes \\
\hline Skin dryness associated with erlotinib & Use an emulsifying cream contains urea & Problem was relieved \\
Dry eyes associated with erlotinib & Use an artificial tears drops for eyes & Problem was relieved \\
Diarrhea associated with erlotinib & Start a loperamid treatment & Symptom was relieved \\
Increase in blood pressure associated & Start an antihypertensive therapy and/or & Blood pressure was controlled \\
with pazopanib & increase the dose of antihypertensive drug & \\
Increase in INR levels associated with pazopanib & Reduce the dose of warfarin & INR levels was at normal range \\
Increase in TSH levels associated with sunitinib & Start a levothyroxine treatment & TSH levels was at normal range \\
\hline
\end{tabular}




\begin{tabular}{|c|c|c|c|c|}
\hline \multirow[b]{2}{*}{$\begin{array}{l}\text { Adverse effects according to the NCI-CTCAE } \\
\text { (11 criteria) }\end{array}$} & \multirow[b]{2}{*}{$\begin{array}{l}\text { 1st } \\
(n=55)\end{array}$} & \multicolumn{3}{|c|}{ Visits $\left(n^{*}\right)$} \\
\hline & & $\begin{array}{l}\text { 2nd } \\
(n=37)\end{array}$ & $\begin{array}{l}\text { 3rd } \\
(n=13)\end{array}$ & $\mathbf{p}^{\star *}$ \\
\hline $\begin{array}{l}\text { Blood and lymphatic system disorders (anemia, decreased } \\
\text { platelet count and/or white blood cell) }\end{array}$ & 9 & 8 & 3 & 0.727 \\
\hline Infections and infestations (lung infection) & 3 & 0 & 0 & - \\
\hline Renal and urinary disorders (acute kidney injury, hematuria) & 6 & 3 & 4 & 0.375 \\
\hline $\begin{array}{l}\text { Gastrointestinal disorders (nausea, vomiting, diarrhea, } \\
\text { constipation, mucositis oral, salivary duct inflammation) }\end{array}$ & 19 & 7 & 2 & 0.001 \\
\hline $\begin{array}{l}\text { Hepatobiliary disorders (bilirubin, alanine aminotransferase- } \\
\text { aspartate aminotransferase levels) }\end{array}$ & 7 & 5 & 2 & 0.688 \\
\hline Nervous systems disorders (headache) & 16 & 13 & 1 & 0.508 \\
\hline Cardiac disorders (atrial fibrillation) & 1 & 0 & 0 & - \\
\hline Respiratory, thoracic, and mediastinal disorders (cough) & 3 & 1 & 1 & 0.500 \\
\hline $\begin{array}{l}\text { Skin and subcutaneous tissue disorders (alopecia, dry skin, } \\
\text { nail discoloration, pruritus, rash acneiform) }\end{array}$ & 9 & 5 & 3 & 0.219 \\
\hline Psychiatric disorders (insomnia, depression) & 5 & 8 & 0 & 0.375 \\
\hline $\begin{array}{l}\text { General disorders and administration site conditions } \\
\text { (pain, fatigue) }\end{array}$ & 21 & 17 & 6 & 0.344 \\
\hline Only fatigue & 20 & 12 & 7 & 0.021 \\
\hline
\end{tabular}

TSH levels were increased. The clinical pharmacist recommended to start or change the dose of levothyroxine treatment after liaison with doctors and TSH levels of patients were decreased in the following visits (Figure 1). The median TSH levels were $30.27 \mathrm{uIU} / \mathrm{ml}$ (range 6.87-120) and $6.61 \mathrm{uIU} /$ $\mathrm{ml}$ (range 2.14-48.19) before and after levothyroxine treatment respectively $(\mathrm{p}=0.012)$. The accepted normal range of TSH was 0.38-5.33 uIU/ml.

\section{DISCUSSION}

Identification of drug interactions and adverse effects in cancer treatment can be challenging for healthcare care team due to an increased workload in the clinics and undistinguishable symptoms of cancer itself and treatment related side effects. Therefore, it is assumed that TKI-related adverse effects and potential drug interactions can be identified and monitored by the involvement of a clinical pharmacist in treatment of cancer patients.
Previous studies documented the types of adverse effects related with TKIs. Although some adverse effects are seen in different extent among TKIs, the most commonly reported ones are fatigue (46\%), hypothyroidism $(51.2 \%)$, diarrhea (2\%-63\%) and skin rash $(8 \%)^{17-19}$ which were consistent with the results of this study.

Studies indicated that tyrosine kinase inhibitors lead to thyroid dysfunction in various extent ${ }^{20,21}$, however its mechanism is still not clearly understood..$^{22}$ In this study, 8 out of 55 patients (14.5\%) were diagnosed with thyroid dysfunction related to TKIs and TSH levels were at normal range after an initiation of levothyroxine treatment. Close monitoring of TSH levels in patients using TKIs may prevent worsening of symptoms and unwanted long-term consequences.

Almost all TKIs, particularly sunitinib, erlotinib and pazopanib are metabolized by CYP3A4 enzymes in liver. ${ }^{4}$ Thus, the use of strong CYP3A4 


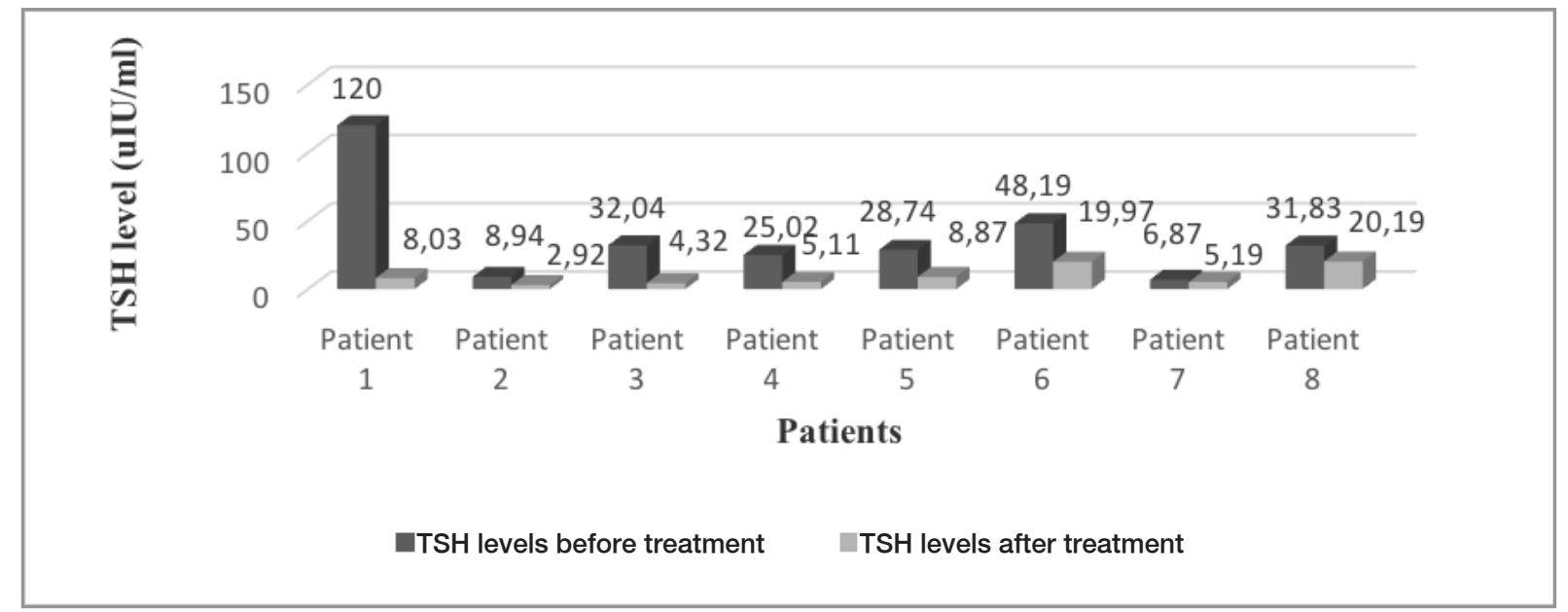

Figure 1. TSH levels of patients using TKls before and after levothyroxine treatment

enzyme inhibitors or inducers should be avoided or an alternative medication, which does not interact with TKIs, should be considered during the treatment. During this study, a clinical pharmacist recommended erlotinib to be used at least 2 hours before pantoprazole (due to the risk of decreased absorption) in patients concurrently use erlotinib and pantoprazole and similarly levothyroxine tablets are recommended to be taken at least 1 hour before omeprazole.

An assessment of drug interactions by different information sources may lead to misinterpretation of its clinical significance with respect to the management. With respect to the interactions with herbal products ( $9.1 \%$ of patients) in this study, the pharmacist advised not to use these products, since literature do not provide any robust evidence to indicate the mechanism and management of those interactions. ${ }^{23-25}$

A combination of chemotherapeutics and use of other medications for comorbid conditions poses a significant risk for drug interactions in cancer treatment. A broad-spectrum of adverse effects of chemotherapeutics along with potential drug interactions may lead to increased toxicity and discontinuation of effective treatments in patients. Therefore, monitoring of patients by a multidisciplinary health care team will help to control these adverse effects and improve treatment outcomes.
Many studies indicate the role of a clinical pharmacist in prevention of drug related problems in cancer patients. ${ }^{6,9,10}$ In accordance with the results of previous studies ${ }^{9,10}$, a majority (94\%) of a clinical pharmacist's recommendations related with adverse effects and drug interactions were accepted by the doctors. A clinical pharmacist retrieved patient's medication history from the medical records or the patients. Unnoticed and/or misinterpreted symptoms by the patients may not be revealed to the pharmacist or doctor which would have effect on the treatment management. Therefore, it is difficult to conclude that whether improvements in symptoms of adverse effects were a result of pharmacist's recommendations or naturally resolved symptoms during treatment.

This study has some limitations. A limited number of patients participated in the study due to a limited period of time ( 7 months) for the recruitment and follow-up. Although it was not the intention of the study to indicate any differences in drug interactions and adverse effects between TKIs, it would have given an insight for incidence of drug interactions and adverse effects, if more patients could be included. Furthermore, not having a control group in the study due to limited participation, did not allow to assess the exact impact of a clinical pharmacist in patient's health outcomes. This was also reported as one of the main limitations in studies that are conducted in oncology outpatient settings. ${ }^{16}$ 
In conclusion, this study investigates the potential involvement of a clinical pharmacist within outpatient clinics in cancer patients in order to identify and solve drug related problems. There should be an opportunity for pharmacists to be involved within outpatient settings for monitoring of drug treatment where a mutual and continuous collaboration between healthcare professionals are established. Therefore, it can be concluded that a constant presence of a clinical pharmacist in the clinics will help to design and establish a new model of care in oncology outpatient clinics which includes the pharmaceutical care for patients.

\section{Acknowledgements:}

The authors would like to thank all participating patients and hospital staff at the outpatient clinic.

\section{REFERENCES}

1. Li N, Yang L, Ou W, et al. Meta-analysis of EGFR tyrosine kinase inhibitors compared with chemotherapy as second-line treatment in pretreated advanced non-small cell lung cancer. PLoS One 9: e102777, 2014.

2. van Erp NP, Gelderblom H, Guchelaar HJ. Clinical pharmacokinetics of tyrosine kinase inhibitors. Cancer Treat Rev 35: 692-706, 2009.

3. Peters S, Zimmermann S, Adjei AA. Oral epidermal growth factor receptor tyrosine kinase inhibitors for the treatment of non-small cell lung cancer: comparative pharmacokinetics and drug-drug interactions. Cancer Treat Rev 40: 917-926, 2014.

4. Shao J, Markowitz JS, Bei D, An G. Enzyme- and transporter-mediated drug interactions with small molecule tyrosine kinase inhibitors. J Pharm Sci 103: 3810-3833, 2014.

5. Keller KL, Franquiz MJ, Duffy AP, Trovato JA. Drug-drug interactions in patients receiving tyrosine kinase inhibitors. J Oncol Pharm Pract, 2016. pii: 1078155216682311. [Epub ahead of print]

6. Leveque D, Delpeuch A, Gourieux B. New anticancer agents: role of clinical pharmacy services. Anticancer Res 34: 15731578, 2014

7. Haouala A, Widmer N, Duchosal MA, et al. Drug interactions with the tyrosine kinase inhibitors imatinib, dasatinib, and nilotinib. Blood 117: e75-87, 2011.

8. Riechelmann RP, Tannock IF, Wang L, et al. Potential drug interactions and duplicate prescriptions among cancer patients. J Natl Cancer Inst 99: 592-600, 2007.
9. Delpeuch A, Leveque D, Gourieux B, Herbrecht R. Impact of clinical pharmacy services in a hematology/oncology inpatient setting. Anticancer Res 35: 457-460, 2015.

10. Yeoh $\Pi$, Si $P$, Chew $L$. The impact of medication therapy management in older oncology patients. Support Care Cancer 21: 1287-1293, 2013.

11. Kimura M, Go M, Iwai M, et al. Evaluation of the role and usefulness of a pharmacist outpatient service for patients undergoing monotherapy with oral anti-cancer agents. J Oncol Pharm Pract 23: 413-421, 2017.

12. Bremberg ER, Hising $\mathrm{C}$, Nylen $\mathrm{U}$, et al. An evaluation of pharmacist contribution to an oncology ward in a Swedish hospital. J Oncol Pharm Pract 12: 75-81, 2006.

13. Shah S, Dowell J, Greene S. Evaluation of clinical pharmacy services in a hematology/oncology outpatient setting. Ann Pharmacother 40: 1527-1533, 2006.

14. Shah NN, Casella E, Capozzi D, et al. Improving the Safety of Oral Chemotherapy at an Academic Medical Center. J Oncol Pract 12: e71-76, 2016.

15. Moulin SM, Eutropio FJ, Souza JO, et al. The role of clinical pharmacists in treatment adherence: fast impact in suppression of chronic myeloid leukemia development and symptoms. Support Care Cancer 25: 951-955, 2017.

16. Colombo LRP, Aguiar PM, Lima TM, Storpirtis S. The effects of pharmacist interventions on adult outpatients with cancer: A systematic review. J Clin Pharm Ther 42: 414-424, 2017.

17. Hutson TE, Davis ID, Machiels JP, et al. Efficacy and safety of pazopanib in patients with metastatic renal cell carcinoma. $J$ Clin Oncol 28: 475-480, 2010.

18. Boyer M, Horwood K, Pavlakis N, et al. Efficacy of erlotinib in patients with advanced non-small-cell lung cancer (NSCLC): analysis of the Australian subpopulation of the TRUST study. Asia Pac J Clin Oncol 8: 248-254, 2012.

19. Tassi R, Baldazzi V, Lapini A, et al. Hyperlipidemia and hypothyroidism among metastatic renal cell carcinoma patients taking sunitinib malate. Related or unrelated adverse events? Clin Genitourin Cancer 13: e101-105, 2015.

20. LaPlant KD, Louzon PD. Pazopanib: an oral multitargeted tyrosine kinase inhibitor for use in renal cell carcinoma. Ann Pharmacother 44: 1054-60, 2010.

21. Taneja SS. Re: Comparative effectiveness of axitinib versus sorafenib in advanced renal cell carcinoma (AXIS): a randomised phase 3 trial. J Urol 188: 412-413, 2012.

22. Fujiwara $\mathrm{Y}$, Kiyota N, Chayahara N, et al. Management of axitinib (AG-013736)-induced fatigue and thyroid dysfunction, and predictive biomarkers of axitinib exposure: results from phase I studies in Japanese patients. Invest New Drugs 30: 1055-1064, 2012

23. Bonifert G, Folkes L, Gmeiner C, et al. Recombinant horseradish peroxidase variants for targeted cancer treatment. Cancer Med 5: 1194-1203, 2016. 
International Journal of Hematology and Oncology

24. Bar-Sela G, Cohen M, Ben-Arye, E, Epelbaum R. The Medical use of wheatgrass: review of the gap between basic and clinical applications. Mini Rev Med Chem 15: 1002-10, 2015.

25. Kapoor R, Ronnenberg A, Puleo E, et al. Effects of Pomegranate Juice on Hormonal Biomarkers of Breast Cancer Risk. Nutr Cancer 67: 1113-1119, 2015.

\section{Correspondence}

Aygin BAYRAKTAR-EKINCIOĞLU

Hacettepe Universitesi, Eczacllık Fakültesi

Klinik Eczacılık Anabilim Dalı

06100 Shhıye, ANKARA / TURKEY

Tel: (+90-312) 3052043

e-mail: aygin77@gmail.com

aygin@hacettepe.edu.tr 